\title{
Native and Alien Plant Species Richness Response to Soil Nitrogen and Phosphorus in Temperate Floodplain and Swamp Forests
}

\section{Richard Hrivnák ${ }^{1, *}$, Michal Slezák ${ }^{1,2,3}$, Benjamín Jarčuška ${ }^{4}$, Ivan Jarolímek ${ }^{1}$ and Judita Kochjarová ${ }^{1,5}$}

1 Institute of Botany, Slovak Academy of Sciences, Dúbravská cesta 9, SK-845 23 Bratislava, Slovakia; E-Mails: slezak.miso@gmail.com (M.S.); ivan.jarolimek@savba.sk (I.J.); kochjarova@rec.uniba.sk (J.K.)

2 Department of Biology and Ecology, Faculty of Education, Catholic University, Hrabovská cesta 1, SK-034 01 Ružomberok, Slovakia

3 Department of Phytology, Faculty of Forestry, Technical University in Zvolen, T. G. Masaryka 24, SK-960 53 Zvolen, Slovakia

4 Institute of Forest Ecology, Štúrova 2, SK-960 53 Zvolen, Slovakia; E-Mail: jarcuska@savzv.sk

5 Botanical Garden, Comenius University, SK-038 15 Blatnica, Slovakia

* Author to whom correspondence should be addressed; E-Mail: richard.hrivnak@savba.sk; Tel.: +421-2-59426-172; Fax: +421-2-5447-1948.

Academic Editor: Heinz Rennenberg

Received: 30 June 2015 / Accepted: 22 September 2015 / Published: 7 October 2015

\begin{abstract}
Soil nitrogen and phosphorus are commonly limiting elements affecting plant species richness in temperate zones. Our species richness-ecological study was performed in alder-dominated forests representing temperate floodplains (streamside alder forests of Alnion incanae alliance) and swamp forests (alder carrs of Alnion glutinosae alliance) in the Western Carpathians. Species richness (i.e., the number of vascular plants in a vegetation plot) was analyzed separately for native and alien vascular plants in 240 vegetation plots across the study area covering Slovakia, northern Hungary and southern Poland. The relationship between the species richness of each plant group and total soil nitrogen content, plant-available phosphorus and carbon to nitrogen $(\mathrm{C} / \mathrm{N})$ ratio was analyzed by generalized linear mixed models (GLMM) with Poisson error distribution and log-link function. The number of recorded native and alien species was 17-84 (average 45.4) and 0-9 (average 1.5) species per plot, respectively. The GLMMs were statistically significant
\end{abstract}


$(p<0.001)$ for both plant groups, but the total explained variation was higher for native $(14 \%)$ than alien plants $(9 \%)$. The richness of native species was negatively affected by the total soil nitrogen content and plant-available phosphorus, whereas the $\mathrm{C} / \mathrm{N}$ ratio showed a positive impact. The alien richness was predicted only by the total soil nitrogen content showing a negative effect.

Keywords: alder-dominated forests; diversity; native and alien species; soil nutrients; vascular plants; vegetation

\section{Introduction}

Variation of plant species richness in plant communities can be explained by more than one hundred plausible ecological hypotheses and theories $[1,2]$ with little consensus regarding the nature of causal processes [3]. Experimental and observational biodiversity research recognized habitat productivity as one of the major determinants controlling local species richness of vascular plants (e.g., [4,5]). This relationship originally showed a typical hump-shaped pattern, i.e., the highest species richness is at the intermediate productivity level and gradually declined towards both marginal parts of the productivity gradient [6]. However, this response appeared to be vegetation- and scale-dependent [2,7] and richness has been recently seen, not simply as a function of productivity, but as feedback to influence productivity [8].

While the relationship between habitat productivity and species richness attracted much of the research effort aimed to understand species richness patterns [3], the relationship between species richness and other measured environmental factors is far less well studied [4]. Soil nitrogen and phosphorus play an important role in the regulation of plant growth and the functioning of several ecosystem processes [9]. These nutrients are commonly absorbed from soluble inorganic sources in soil solutions. However, plant uptake strategies and mechanisms related to nutrient acquisition promote resource partitioning and may lead to local species coexistence $[9,10]$. Changes in soil nitrogen and phosphorus availability are reflected either in their concentrations in plant tissues, ratios with other nutrients [11] or in species richness patterns. They are considered to be a limiting soil element affecting species richness of vegetation in temperate zone $[10,12,13]$. The increasing soil nitrogen and phosphorus content usually reduces the richness of herb layer vascular plants (e.g., [14,15]), but unimodal, positive or non-significant effects were also found in empirical studies (e.g., [4,16,17]). These responses are most likely a consequence of diverse nitrogen and phosphorus pools among study sites. While the total soil nitrogen content corresponds especially to its supply in mineral soil and/or thickness of organic layers, the level of phosphorus is driven mainly by abiotic resources and soil age [10]. The effect of soil phosphorus on species richness is much more ambiguous because of interactions with other covariant factors modifying the supply, chemical form and availability of nutrients (e.g., soil reaction, chemistry of geological substrates). The carbon to nitrogen $(\mathrm{C} / \mathrm{N})$ ratio of soil organic matter is a useful indicator of site quality with effects on both forest species composition and richness [18,19]. However, plant species richness in floodplain forests is also driven by several other environmental factors such as soil moisture 
and reaction, landscape configuration and dynamic of water regime [20-22]. These factors can account for a major part of explained variation in the species richness-environmental relationship [20].

Black alder (Alnus glutinosa (L.) Gaertn.) and grey alder (Alnus incana (L.) Moench) represent indigenous tree species to Central Europe, which dominate in floodplains (streamside alder forests, phytosociological alliance Alnion incanae Pawłowski et al. 1928) and swamp forests (alder carrs, Alnion glutinosae Malcuit 1929) [23] (hereinafter alder forests). While Alnus glutinosa can dominate in both vegetation types, Alnus incana almost exclusively prefers streamside alder forests [23]. They grow in habitats with relatively broad ecological gradients including mineral and organic soils [24-26]. Both alder species have constant effect on understory vegetation, as they improve the soil nitrogen pool and consequently modify the $\mathrm{C} / \mathrm{N}$ ratio of the soil organic matter by symbiotic $\mathrm{N}_{2}$-fixation [27]. The alder forests are, thus, commonly referred to as non-nitrogen-limited ecosystems, although a mineralization of organic matter is locally disabled by permanently flooded soils [28]. Alder species also positively affect diversity and activity of soil microbial communities leading to a larger increase in soil phosphorus availability [29]. Therefore, the alder forests represent a proper base for the study of relationships among species richness and soil characteristics.

Invasions of alien plant species, especially neophytes, are considered one of the major threats to the diversity of natural ecosystems including floodplain forests [30-32]. Among natural and semi-natural vegetation types, floodplain forests belong to the most invaded habitats [33]. They usually contain a higher number of alien species compared with all other forest vegetation types [32,34-36]. Plant invasions may, thus, enrich the overall species richness and modify the structure of species composition. The streamside alder forests are particularly highly prone to invasions of alien species, as rivers frequently act as propagule dispersal corridors [37,38]. Moreover, there is a strong human impact on these ecosystems (e.g., forestry, agricultural, both human utilization and activities in forests and surrounding landscape), which enhances the expansion rate of alien species into disturbed habitats.

Alder forests commonly create fragmented and small-scale forest stands due to the changes and transformation of the hydrological regime and fragmentation. These fragments are obviously influenced by adjacent landscape-scale factors [39]. Although these medium to species-rich forests [28,40] belong to threatened habitats at European or national levels (European Habitat Directive 92/43/EEC) [41,42], they represent a relatively frequent habitat in the Western Carpathians [23].

The aim of present study is to assess the relationship between soil nitrogen, plant-available phosphorus, $\mathrm{C} / \mathrm{N}$ ratio and plant species richness in alder forests. Our main questions were: (i) what is the role of soil nitrogen, plant-available phosphorus and $\mathrm{C} / \mathrm{N}$ ratio in the variation of native and alien plant species richness? and (ii) are there differences in responses of both plant groups to these factors? As native and invasive species show differences in their competitive abilities for nutrients [43], we expect different responses of the native and invasive species richness to the explanatory variables.

\section{Material and Methods}

\subsection{Study Area}

The species richness-edaphic relationship in floodplains (streamside alder forests; Alnion incanae) and swamp forests (alder carrs; Alnion glutinosae) was studied across the central part of the Western 
Carpathians, including Slovakia, northern Hungary and southern Poland (Figure 1). Vegetation plots of this territory cover a wide latitudinal $\left(47.829^{\circ}-49.685^{\circ}\right)$ and altitudinal $(131-917 \mathrm{~m})$ range, and include two ecologically and floristically distinctive European biogeographical areas - the Pannonian and Western Carpathian regions. The Pannonian climate shows drier and warmer vegetation seasons and affects the southern part of the study area, whereas the Carpathian climate is more humid and affects the central and northern part. The streamside alder forests prefer riparian zones and spring-fed areas from lowland to mountain regions, with the understory formed mainly by meso to hygrophilous species. In contrast, the crucial plant components of the understory of alder carr forests, frequent especially within lowland catchments, are mainly sedges and perennial grasses [23].

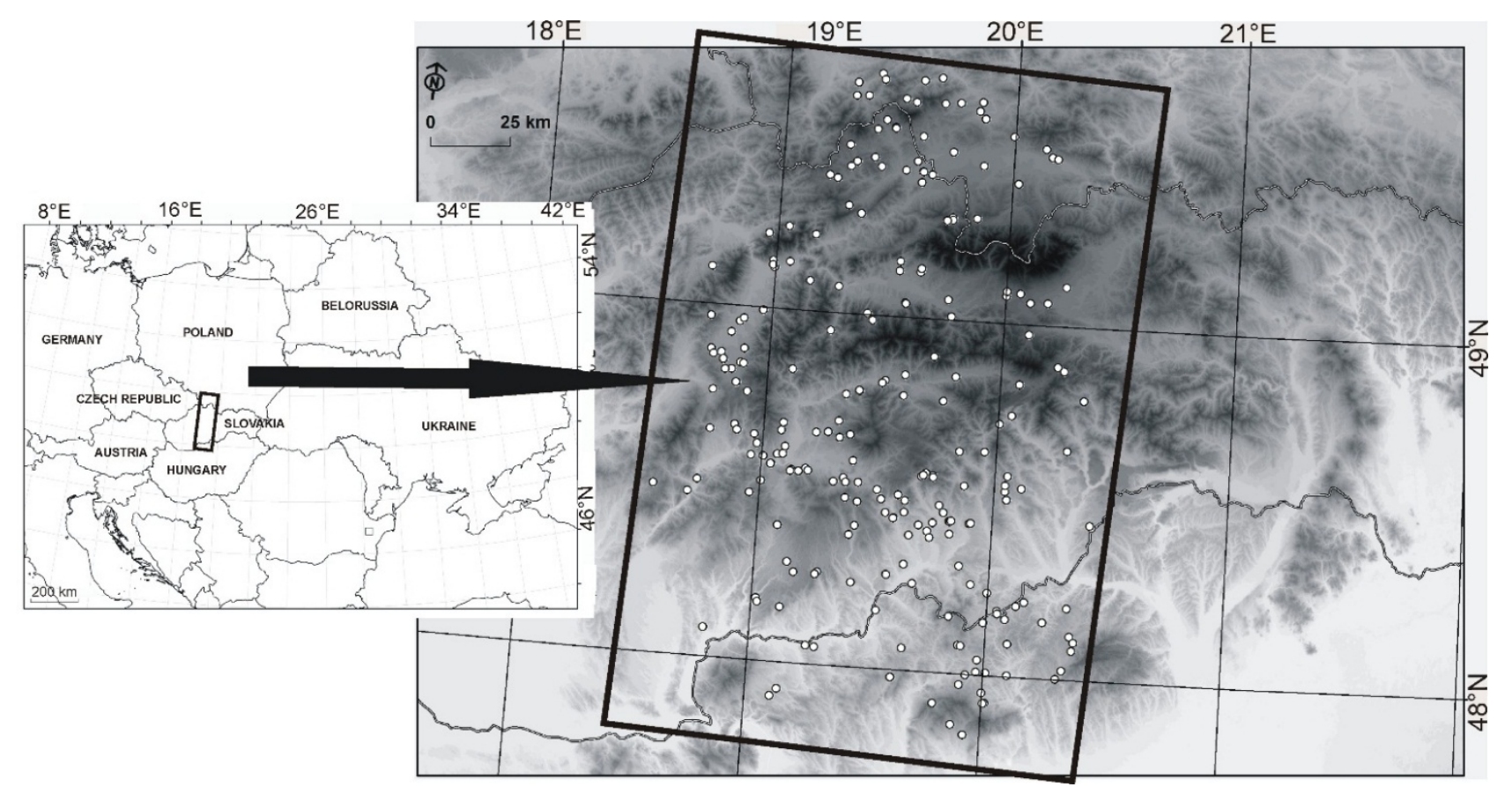

Figure 1. Study area and distribution of vegetation plots.

\subsection{Field Sampling and Laboratory Analyses}

Vegetation and soil variables were sampled in the centre of physiognomically homogeneous forest stands with a dominance of species Alnus glutinosa or A. incana in the tree layer (i.e., canopy cover more than $50 \%$ ). Sampling was carried out in plots with a uniform size of $400 \mathrm{~m}^{2}$. The intensity of sampling in each alder-dominated site corresponded to the environmental heterogeneity and presence of different vegetation types [23]. In more detail, the distance between the two nearest plots of the same vegetation type was usually at least $4 \mathrm{~km}$. In case the habitat conditions of the alder-dominated site were considerably variable, which was obvious in the species composition pattern, we decided to sample more than one plot. Two hundred and forty plots were sampled between June and August from 2010-2014. They were originally collected for the purpose of phytosociological classification using the standard European phytosociological approach [44]; results were published recently in Slovakia [23]. Each plot contained a list of all present vascular plant species. Species nomenclature and taxonomy were unified according to the checklist of Marhold and Hindák [45]. The plant species were divided into two groups, native and alien species based on a checklist of non-native plants in Slovakia [46]. Species richness 
(i.e., the number of species per sampling plot) was determined for both plant groups. This dataset was stored in the Institute of Botany SAS as an xls-file.

Soil samples were randomly taken in three places in various parts of each plot from the uppermost mineral horizon (0-10 cm depth, litter removed) and mixed to form a single sample (weight approximately $1 \mathrm{~kg}$ ) per plot in order to reduce the soil heterogeneity. They were dried at a laboratory temperature, crushed and passed through a $2 \mathrm{~mm}$ sieve. Soil analyses were performed on air-dried samples following standard protocols. Total carbon $(\mathrm{C})$ and total nitrogen $(\mathrm{N})$ contents were determined using an NCS-FLASH 1112 analyzer (CE Instruments, UK) and subsequently, the C/N-ratio as an appropriate surrogate for the mineralization rate [47] was calculated. Plant-available phosphorus (P) was extracted using the Mehlich II solution [48] and measured by spectrophotometry (AES-ICP).

\subsection{Data Analysis}

The variation in species richness of native and alien vascular plants explained by the soil variables was analyzed using the generalized linear models (GLM) and generalized linear mixed models (GLMM). Poisson error distribution and log-link function were initially applied in model specification. Since over dispersion and presence of some spatial structure in the GLMs' residuals were observed (for more details see [49,50]), spatial GLMM with penalized quasi-likelihood (glmmPQL; library "MASS") [51] was used finally. This modeling procedure allows the use of spatially structured random effects. Gaussian correlation structure was used in the GLMMs. However, differences between these models - accounting for spatial autocorrelation - and GLM-models were slight.

Quadratic terms for all explanatory variables (after centering) were also meant to be included in the models. However, only the squared $\mathrm{C} / \mathrm{N}$-ratio entered the models due to collinearity $(R>0.60)$ of quadratic terms. Two models (i) containing only main effects and (ii) with second order interactions between explanatory variables were created for both native and alien species richness.

The graphic distribution of model's residuals was assessed by plotting of the standardized residuals against the values predicted by the model, as well as against each explanatory variable. The spatial autocorrelation of model's residuals was checked by the global Moran's I test (library "ape") [52]. The spatial autocorrelation in response to distance was assessed by a Moran's I correlogram with an increment of 2 (library "ncf”) [53]. The proportion of explained variation in glmmPQL (pseudo-R2 value; hereinafter, R2) was calculated as the squared Pearson correlation coefficient between observed and predicted values [54]. All statistical analyses were performed in the R version 3.0.0 [55] through the integrated development environment RStudio [56].

\section{Results}

Altogether, 490 vascular plant species were recorded in 240 vegetation plots of alder forests. The total number of species ranged from 17 to 92 per plot. Native species created a substantial part of the total species richness, whereas the number of alien species was considerably lower, but had obvious variance among particular plots. The values of studied soil characteristics were relatively variable in plots (Table 1). 
Table 1. Descriptive statistics of species richness characteristics and ecological variables $(n=240)$.

\begin{tabular}{ccccc}
\hline & Average \pm S.D. & Min. & Max. & C.V. \\
\hline Vegetation Characteristics & & & & \\
\hline Number of native species & $45.4 \pm 11.8$ & 17 & 84 & 25.9 \\
Number of alien species & $1.5 \pm 1.8$ & 0 & 9 & 121.8 \\
\hline Soil Variables & & & & \\
\hline Total N (\%) & $0.599 \pm 0.468$ & 0.080 & 2.549 & 79.6 \\
P (mg/kg) & $17.702 \pm 9.546$ & 0.500 & 64.290 & 53.9 \\
Total C (\%) & $7.651 \pm 6.153$ & 1.000 & 31.727 & 82.0 \\
C/N ratio & $12.882 \pm 3.170$ & 4.929 & 25.189 & 24.6 \\
\hline
\end{tabular}

S.D.: standard deviation, CV: coefficient of variation.

The main effects models and the models with second order interactions between soil variables accounted for a comparable proportion of data variability (14\% and 16\%, respectively) (Tables 2 and 3 ). Total explained variability in species richness of vascular plants was higher for native (14\%) than alien $(9 \%)$ species. While the species richness of native plants was significantly related to all analyzed variables, the richness pattern of aliens was affected by only one predictor (Table 2). Higher concentrations of plant-available phosphorus and total nitrogen reduced the species richness of native plants, whereas the $\mathrm{C} / \mathrm{N}$ ratio showed a positive effect. The alien species richness was negatively related to the total nitrogen content (Figure 2). Second order interactions between the soil variables did not explain the variability of species richness either in native or alien plant species (Table 3 ).

Table 2. Main effects models with the number of native and alien plants as a response to ecological variables, respectively.

\begin{tabular}{ccccccccc}
\hline \multicolumn{9}{c}{ Native Species } \\
\hline & Estimate & S.E. & $\boldsymbol{t}$ & $\boldsymbol{P}$ & Estimate & S.E. & $\boldsymbol{t}$ & $\boldsymbol{P}$ \\
\hline (Intercept) & 3.8243 & 0.0182 & 210.02 & $<0.001$ & 0.4036 & 0.0850 & 4.75 & $<0.001$ \\
Total N & -0.0790 & 0.0340 & -2.32 & $\mathbf{0 . 0 2 1}$ & -0.6019 & 0.1506 & -4.00 & $<\mathbf{0 . 0 0 1}$ \\
$\mathrm{P}$ & -0.0068 & 0.0018 & -3.87 & $<\mathbf{0 . 0 0 1}$ & 0.0088 & 0.0071 & 1.25 & 0.213 \\
$\mathrm{C} / \mathrm{N}$ & 0.0217 & 0.0061 & 3.53 & $<\mathbf{0 . 0 0 1}$ & -0.0188 & 0.0232 & -0.81 & 0.419 \\
$\mathrm{C} / \mathrm{N}^{2}$ & -0.0016 & 0.0009 & -1.77 & 0.08 & -0.0043 & 0.0039 & -1.11 & 0.269 \\
$R^{2}$ & 0.14 & $p<0.001$ & & & 0.09 & $p<0.001$ & & \\
\hline
\end{tabular}

S.E.: standard error; $\mathrm{df}=235$; for $R^{2}$ calculation see Data analysis.

Table 3. Second order interactions models with the number of native and alien plants as response variables, respectively.

\begin{tabular}{ccccccccc}
\hline & \multicolumn{3}{c}{ Native Species } & \multicolumn{4}{c}{ Alien Species } \\
\hline & Estimate & S.E. & $\boldsymbol{t}$ & $\boldsymbol{P}$ & Estimate & S.E. & $\boldsymbol{t}$ & $\boldsymbol{P}$ \\
\hline (Intercept) & 3.8247 & 0.0189 & 202.81 & $<0.001$ & 0.4176 & 0.0872 & 4.79 & $<0.001$ \\
Total N (1) & -0.1057 & 0.0354 & -2.99 & $\mathbf{0 . 0 0 3}$ & -0.4653 & 0.1494 & -3.11 & $\mathbf{0 . 0 0 2}$ \\
$\mathrm{P}(2)$ & -0.0060 & 0.0020 & -2.97 & $\mathbf{0 . 0 0 3}$ & 0.0029 & 0.0082 & 0.36 & 0.722 \\
$\mathrm{C} / \mathrm{N}(3)$ & 0.0074 & 0.0086 & 0.86 & 0.392 & -0.0620 & 0.0376 & -1.65 & 0.100 \\
$\mathrm{C} / \mathrm{N}^{2}(4)$ & -0.0021 & 0.0015 & -1.40 & 0.164 & -0.0125 & 0.0068 & -1.85 & 0.066 \\
$1 \times 2$ & -0.0051 & 0.0041 & -1.26 & 0.207 & -0.0087 & 0.0176 & -0.50 & 0.620 \\
\hline
\end{tabular}


Table 3. Cont.

\begin{tabular}{ccccccccc}
\hline & \multicolumn{4}{c}{ Native Species } & \multicolumn{5}{c}{ Alien Species } \\
\hline & Estimate & S.E. & $\boldsymbol{t}$ & $\boldsymbol{P}$ & Estimate & S.E. & $\boldsymbol{t}$ & $\boldsymbol{P}$ \\
\hline $1 \times 3$ & -0.0297 & 0.0205 & -1.44 & 0.149 & 0.0170 & 0.0930 & 0.18 & 0.855 \\
$1 \times 4$ & 0.0019 & 0.0041 & 0.49 & 0.626 & -0.0107 & 0.0192 & -0.56 & 0.577 \\
$2 \times 3$ & -0.00002 & 0.0008 & -0.02 & 0.985 & -0.0040 & 0.0030 & -1.34 & 0.183 \\
$2 \times 4$ & -0.0002 & 0.0001 & -1.20 & 0.230 & 0.00004 & 0.0005 & 0.09 & 0.932 \\
$3 \times 4$ & -0.0002 & 0.0002 & 0.96 & 0.336 & 0.0012 & 0.0007 & 1.56 & 0.120 \\
$R^{2}$ & 0.16 & $p<0.001$ & & & 0.08 & $p<0.001$ & & \\
\hline
\end{tabular}

S.E.: standard error; $\mathrm{df}=229$; for $R^{2}$ calculation see Data analysis.

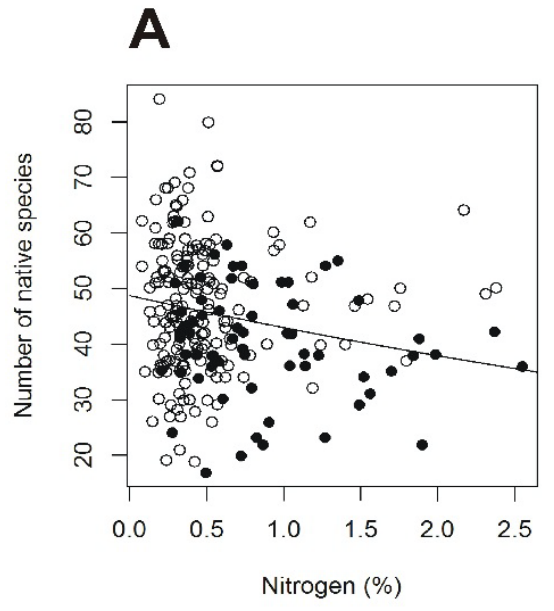

B

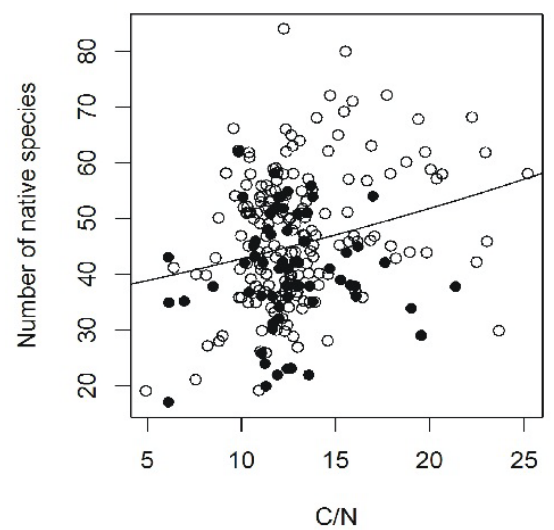

C

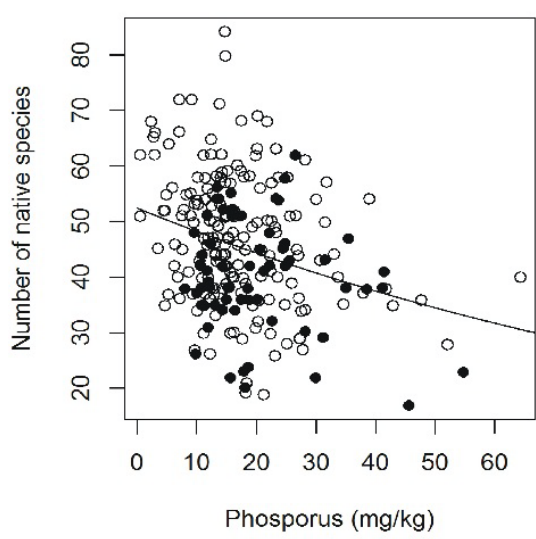

D

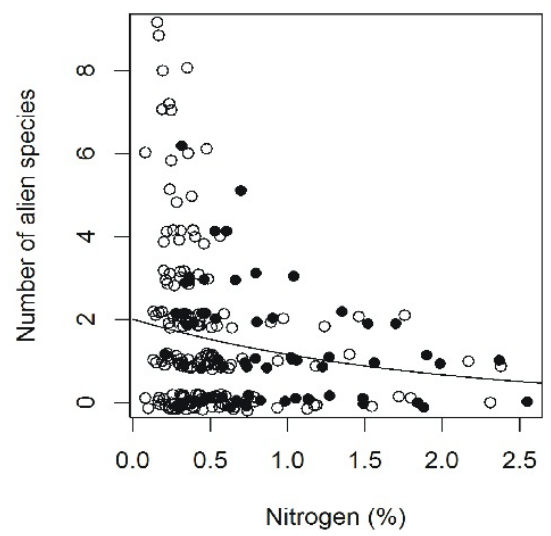

Figure 2. Relationship between species richness of native $(\mathbf{A}-\mathbf{C})$ and alien $(\mathbf{D})$ vascular plants and ecological variables, which were statistically significant in the used model (empty circles — streamside alder forests, full circles — alder carrs).

\section{Discussion}

The present study showed a negative effect of total nitrogen on species richness for both native and alien plant species. Although some previous studies focusing on diversity research in forest understory vegetation found the unimodal response (e.g., [6]), this negative trend (i.e., a higher amount of soil nitrogen led to a lower number of species) was most often identified in temperate deciduous 
forests $[14,16,17]$. The differences in the species richness trends along the nitrogen gradient can be partially addressed to habitat-related biases (e.g., restricted length of analyzed nitrogen gradient). Thus, the final response of plant species richness along the productivity gradient generally appears to be dependent on the inclusion of extreme habitats on the gradient $[6,14]$. We do not suppose this pattern to be relevant in our study, as the analyzed data covered the whole vegetation and nitrogen gradient of the alder forests in the Western Carpathians.

The negative effect of soil nitrogen content on species richness can be explained by a potential positive effect of nitrogen on certain highly competitive plants [16,21]. These species may have suppressed competitively weaker species. In our data, the nitrogen-rich sites are usually covered by dominant species such as Caltha palustris, Carex acutiformis, Petasites hybridus or Phragmites australis. We expected differences in total nitrogen-species richness pattern for the native and alien species, as they differ in their strategies for growth and survival in habitats [43]. However, the negative response of species richness to soil nitrogen was consistent between groups. Similarly, Jones and Chapman [17] found a negative decreasing trend in both cases of native and alien species in Pennsylvania oak forests. In addition, the highest variability of alien species richness was documented at lower parts of the nitrogen gradient in our study, which could affect the number of alien species-nitrogen relationships. Similarly to alder forests, the highest variability of species richness at lower part of nitrogen gradient has also been observed in other forests [17].

$\mathrm{The} \mathrm{C} / \mathrm{N}$ ratio had a positive effect on the species richness of native plants. Our findings differed from those observed in German floodplain forests [19,57], where no relationship between $\mathrm{C} / \mathrm{N}$ ratio and plant species richness was found. Similarly, positive trends and/or slightly convex curves were also identified in deciduous forests by Schuster and Diekmann [4]. The $\mathrm{C} / \mathrm{N}$ ratio of soil organic matter was related to a nitrogen immobilization and mineralization during decomposition by microorganisms [18,58]. Alder forests of European temperate zone create two main vegetation groups, which vary in their environmental conditions, including their affinity for soil substrates. Species-richer streamside alder forests show better soil mineralization [28] and higher $\mathrm{C} / \mathrm{N}$ ratio than species-poorer alder carrs. In our data, the ten most species-rich sites corresponded to the streamside alder forests (average $\mathrm{C} / \mathrm{N}$ ratio $=14.15$ ), whereas ten most species-poor sites were mostly swamp forests with a $\mathrm{C} / \mathrm{N}$ ratio of 11.12 (see also Figure 2). Increasing species richness along the $\mathrm{C} / \mathrm{N}$ ratio gradient in the total data set of alder forests is therefore logical and expected, although it does not agree with findings reported from mesic deciduous forests. In addition, a positive correlation between $\mathrm{C} / \mathrm{N}$ ratio and species richness most likely corresponds to a negative effect of nitrogen on species richness.

Plant-available phosphorus was the most variable soil characteristic in our study (Table 1). Similar soil phosphorus concentrations were also documented in temperate floodplain and swamp alder forests of the south-western Poland [59]. Diverse forms of soil phosphorus support niche differentiation and facilitate plant species coexistence [60], but plant species richness commonly declines along an increasing soil phosphorus gradient $[15,61]$. The negative species richness-phosphorus relationship was also found in the present study for native vascular plants. High soil phosphorus content promotes vigorous growth, especially in fast-colonizing, competitive species, and reduces the species richness of vascular plants in broadleaved deciduous forests $[16,62]$. Phosphorus-rich sites in studied alder forests were dominated mainly by highly productive clonal species, most often by Urtica dioica. The high availability of soil phosphorus favors species Urtica dioica during successful development and strong 
competition [63]. Indeed, clonal species with lateral spreading are able to reallocate resources among individual ramets growing in patches with diverse nutrient-availability [22]. Thus, their competitive advantage at high phosphorus levels can suppress the colonization and successful establishment of other plant species and, consequently, can lead to the species richness decline. Although these species occurred at phosphorus-poorer sites as well, they reached only an additional cover value within the herb layer vegetation. Changes in dominant species at phosphorus-rich grassland sites are usually accompanied by changes in overall species composition and vegetation [61], but we did not observe this pattern in alder forests.

It is important to note that the soil variables (total nitrogen, plant-available phosphorus and $\mathrm{C} / \mathrm{N}$ ratio) used as explanatory variables in our study explained together only between 8 and $16 \%$ of the variability in alien and native species richness in alder forests' understories, respectively. For a complex interpretation of variation in species richness or composition of vascular plants in streamside and alder carr forests, other habitat quality and landscape configuration-related factors have to be taken into account as well $[20,21,39]$. In more detail, habitat quality parameters, such as hydrological characteristics (e.g., water table, flooding), soil nutrient/acidity complex, temperature and light availability represent significant variables controlling vegetation structure of alder forests [20,22]. Moreover, the portion of surrounding country, distance to settlements or distance from the stream source plays the important role, as well [20,22,39]. These drivers could explain the major part of the variation in species richness-environmental relationships within temperate floodplain and swamp forests.

\section{Acknowledgments}

We would like to thank Dušan Senko for the preparation of the map. The research was supported by the Science Grant Agency of the Ministry of Education of the Slovak Republic and the Slovak Academy of Sciences (VEGA 2/0019/14 and 2/0051/15) and COST project "European Information System for Alien Species".

\section{Author Contributions}

We declare the following concerning the authors' contributions to the research: fieldwork: Richard Hrivnák, Michal Slezák, Judita Kochjarová, Ivan Jarolímek; manuscript preparation: Richard Hrivnák, Michal Slezák, Benjamín Jarčuška, Ivan Jarolímek; data analyses: Benjamín Jarčuška.

\section{Conflicts of Interest}

The authors declare no conflict of interest.

\section{References}

1. Palmer, M.W. Variation in species richness: Towards a unification of hypotheses. Folia Geobot. Phytotaxon. 1994, 29, 511-530.

2. Grace, J.B. The factors controlling species density in herbaceous plant communities: An assessment. Perspect. Plant Ecol. Evol. Syst. 1999, 2, 1-28. 
3. Gillman, L.N.; Wright, S.D. The influence of productivity on the species richness of plants: A critical assessment. Ecology 2006, 87, 1234-1243.

4. Schuster, B.; Diekmann, M. Species richness and environmental correlates in deciduous forests of Northwest Germany. For. Ecol. Manag. 2005, 206, 197-205.

5. Axmanová, I.; Chytrý, M.; Zelený, D.; Li, C.-F.; Vymazalová, M.; Danihelka, J.; Horsák, M.; Kočí, M.; Kubešová, S.; Lososová, Z.; et al. The species richness-productivity relationship in the herb layer of European deciduous forests. Glob. Ecol. Biogeogr. 2012, 21, 657-667.

6. Pausas, J.G.; Austin, M.P. Patterns of plant species richness in relation to different environments: An appraisal. J. Veg. Sci. 2001, 12, 153-166.

7. Waide, R.B.; Willing, M.R.; Steiner, C.F.; Mittelbach, G.; Gough, L.; Dodson, S.I.; Juday, G.P.; Parmenter, R. The relationship between productivity and species richness. Annu. Rev. Ecol. Syst. 1999, 30, 257-300.

8. Adler, P.B.; Seabloom, E.W.; Borer, E.T.; Hillebrand, H.; Hautier, Y.; Hector, A.; Harpole, W.S.; O'Halloran, L.R.; Grace, J.B.; Anderson, T.M.; et al. Productivity is a poor predictor of plant species richness. Science 2011, 333, 1750-1753.

9. Lambers, H.; Brundrett, M.C.; Raven, J.A.; Hopper, S.D. Plant mineral nutrition in ancient landscape: High plant species diversity on infertile soils is linked to functional diversity for nutritional strategies. Plant Soil 2010, 334, 11-31.

10. Lambers, H.; Raven, J.A.; Shaver, G.R.; Smith, S.E. Plant nutrient-acquisition strategies change with soil age. Trends Ecol. Evol. 2008, 23, 95-103.

11. Güsewell, S. N:P ratios in terrestrial plants: variation and functional significance. New Phytol. 2004, 164, 243-266.

12. Attiwill, P.M.; Adams, M.A. Nutrient cycling in forests. New Phytol. 1993, 124, 561-582.

13. Vitousek, P.M.; Porder, S.; Houlton, B.Z.; Chadwick, O.A. Terrestrial phosphorus limitation: Mechanisms, implications, and nitrogen-phosphorus interactions. Ecol. Appl. 2010, 20, 5-15.

14. Dupré, C.; Wessberg, C.; Diekmann, M. Species richness in deciduous forests: Effects of species pools and environmental variables. J. Veg. Sci. 2002, 13, 505-516.

15. Dumortier, M.; Butaye, J.; Jacquemyn, H.; van Camp, N.; Lust, N.; Hermy, M. Predicting vascular plant species richness of fragmented forests in agricultural landscapes in central Belgium. For. Ecol. Manag. 2002, 158, 85-102.

16. Hofmeister, J.; Hošek, J.; Modrý, M.; Roleček, J. The influence of light and nutrient availability on herb layer species richness in oak-dominated forests in central Bohemia. Plant Ecol. 2009, 205, $57-75$.

17. Jones, R.O.; Chapman, S.K. The roles of biotic resistance and nitrogen deposition in regulating non-native understory plant diversity. Plant Soil 2011, 345, 257-269.

18. Yakamura, T.; Sahunalu, P. Soil carbon/nitrogen ratio as a site quality index for some South-east Asian forests. J. Trop. Ecol. 1990, 6, 371-378.

19. Härdtle, W.; von Oheimb, G.; Westphal, C. The effects of light and soil conditions on the species richness of the ground vegetation of deciduous forests in northern Germany (Schleswig-Holstein). For. Ecol. Manag. 2003, 182, 327-338.

20. Douda, J. The role of landscape configuration in plant composition of floodplain forests across different physiographic areas. J. Veg. Sci. 2010, 21, 1110-1124. 
21. Mölder, A.; Schneider, E. On the beautiful diverse Danube? Danubian floodplain forest vegetation and flora under the influence of river eutrophication. River Res. Appl. 2011, 27, 881-894.

22. Douda, J.; Doudová-Kochánková, J.; Boublík, K.; Drašnarová, A. Plant species coexistence at local scale in temperate swamp forest: Test of habitat heterogeneity hypothesis. Oecologia 2012, $169,523-534$.

23. Slezák, M.; Hrivnák, R.; Petrášová, A. Numerical classification of alder carr and riparian alder forests in Slovakia. Phytocoenologia 2014, 44, 283-308.

24. McVean, D.N. Biological flora of the British Isles. Alnus glutinosa (L.) Gaertn. J. Ecol. 1953, 41, 447-466.

25. Schwabe, A. Monographie Alnus incana-reicher Waldgesellschaften in Europa Variabilität und Ähnlichkeit einer azonal verbreiteten Gesellschaftsgruppe. Phytocoenologia 1985, 13, 197-302.

26. Claessens, H.; Oosterbaan, A.; Savill, P.; Rondeux, J. A review of the characteristics of black alder (Alnus glutinosa (L.) Gaertn.) and their implications for silvicultural practises. Forestry 2010, 83, $163-175$.

27. Eickenscheidt, T.; Heinichen, J.; Augustin, J.; Freibauer, A.; Drösler, M. Nitrogen mineralization and gaseous nitrogen losses from waterlogged and drained organic soils in a black alder (Alnus glutinosa (L.) Gaertn.) forest. Biogeosciences 2014, 11, 2961-2976.

28. Ellenberg, H. Vegetation Ecology of Central Europe; Cambridge University Press: New York, NY, USA, 2009; pp. 1-731.

29. Lõhmus, K.; Truu, M.; Truu, J.; Ostonen, I.; Kaar, E.; Vares, A.; Uri, V.; Alama, S.; Kanal, A. Functional diversity of culturable bacterial communities in the rhizosphere in relation to fine-root and soil parameters in alder stands on forests, abandoned agricultural, and oil-shale mining areas. Plant Soil 2006, 283, 1-10.

30. Kowarik, I. Biologische Invasionen: Neophyten und Neozoen in Mitteleuropa; Ulmer: Stuttgart, Germany, 2003; pp. 1-492.

31. Weber, E. Invasive Plant Species of the World: A Reference Guide to Environmental Weeds; CAB International Publ.: Wallingford, UK, 2003; pp. 1-548.

32. Pyšek, P.; Bacher, S.; Chytrý, M.; Jarošík, V.; Wild, J.; Celesti-Grapow, L.; Gassó, N.; Kenis, M.; Lambdon, P.W.; Nentwig, W.; et al. Contrasting patterns in the invasions of European terrestrial and freshwater habitats by alien plants, insects and vertebrates. Glob. Ecol. Biogeogr. 2010, 19, $317-331$.

33. Richardson, D.M.; Holmes, P.M.; Esler, K.J.; Galatowitsch, S.M.; Stromberg, J.G.; Kirkman, S.P.; Pyšek, P.; Hobbs, R.J. Riparian vegetation: Degradation, alien plant invasions, and restoration prospects. Divers. Distrib. 2007, 13, 126-139.

34. Medvecká, J.; Jarolímek, I.; Senko, D.; Svitok, M. Fifty years of plant invasion dynamics in Slovakia along a $2500 \mathrm{~m}$ altitudinal gradient. Biol. Invasions 2014, 16, 1627-1638.

35. Walter, J.; Essl, F.; Englisch, T.; Kiehn, M. Neophytes in Austria: Habitat preferences and ecological effects. Neobiota 2005, 6, 13-25.

36. Vilá, M.; Pino, J.; Font, X. Regional assesment of plant invasions across different habitat types. J. Veg. Sci. 2007, 18, 35-42.

37. Burkart, M. River corridor plants (Stromtalpflanzen) in Central European lowland: A review of a poorly understood plant distribution pattern. Glob. Ecol. Biogeogr. 2001, 10, 449-468. 
38. Zając, A.; Tokarska-Guzik, B.; Zając, M. The role of rivers and streams in the migration of alien plants into the Polish Carpathians. Biodivers. Res. Conserv. 2011, 23, 43-56.

39. Pielech, R.; Aniot-Kwiatkowska, J.; Szczęśniak, E. Landscape-scale factors driving plant species composition in mountain streamside and spring riparian forests. For. Ecol. Manag. 2015, 347, 217-227.

40. Chytrý, M.; Dražil, T.; Hájek, M.; Kalníková, V.; Preislerová, Z.; Šibík, J.; Ujházy, K.; Axmanová, I.; Bernátová, D.; Blanár, D.; et al. The most species-rich plant communities of the Czech Republic and Slovakia (with new world records). Preslia 2015, 87, 217-278.

41. Stanová, V.; Valachovič, M. Katalóg Biotopov Slovenska; DAPHNE_-Inštitút aplikovanej ekológie: Bratislava, Slovakia, 2002; pp. 1-225.

42. Bölöni, J.; Molnár, Z.; Kun, A. Magyarország Élöhelyei Vegetációtípusok Leirása és Határozója. Ánér 2011; MTA Ökológiai és Botanikai Kutatóintézete: Vácrátót, Hungary, 2011; pp. 1-441.

43. Davis, M.A.; Grime, J.P.; Thomson, K. Fluctuating resources in plant communities: A general theory of invisibility. J. Ecol. 2000, 88, 528-534.

44. Dengler, J.; Chytrý, M.; Ewald, J. Phytosociology. In Encyclopedia of Ecology; Jørgensen, S.E., Fath, B.D., Eds.; Elsevier: Oxford, UK, 2008; Volume 4, pp. 2767-2779.

45. Marhold, K.; Hindák, F. Zoznam nižších a vyšších rastlín Slovenska; Veda: Bratislava, Slovakia, 1998; pp. 1-688.

46. Medvecká, J.; Kliment, J.; Májeková, J.; Halada, L.; Zaliberová, M.; Gojdičová, E.; Feráková, V.; Jarolímek, I. Inventory of alien species of Slovakia. Preslia 2012, 84, 257-309.

47. Finzi, A.C.; van Breemen, N.; Canham, C.D. Canopy tree-soil interactions within temperate forests: species effects on soil carbon and nitrogen. Ecol. Appl. 1998, 8, 440-446.

48. Mehlich, A. New extractant for soil test evaluation of phosphorus, potassium, magnesium, calcium, sodium, manganese, and zinc. Commun. Soil Sci. Plant Anal. 1978, 9, 477-492.

49. Dormann, C.F.; McPherson, J.M.; Araújo, M.B.; Bivand, R.; Bolliger, J.; Carl, G.; Davies, R.G.; Hirzel, A.; Jetz, W.; Kissling, W.D.; et al. Methods to account for spatial autocorrelation in the analysis of species distributional data: a review. Ecography 2007, 30, 609-628.

50. Beale, C.M.; Lennon, J.J.; Yearsley, J.M.; Brewer, M.J.; Elston, D.A. Regression analysis of spatial data. Ecol. Lett. 2010, 13, 246-264.

51. Venables, W.N.; Ripley, B.D. Modern Applied Statistics with S; Springer: New York, NY, USA, 2002; pp. 1-495.

52. Paradis, E.; Claude, J.; Strimmer, K. APE: Analyses of phylogenetics and evolution in R language. Bioinformatics 2004, 20, 289-290.

53. Bjornstad, O.N. Ncf: Spatial Nonparametric Covariance Functions; R package version 1.1-5, 2013. Available online: http://onb.ent.psu.edu/onb1/Rs (accessed on 2 April 2015).

54. Kissling, W.D.; Carl, G. Spatial autocorrelation and the selection of simultaneous autoregressive models. Glob. Ecol. Biogeogr. 2008, 17, 59-71.

55. R Core Team. R: A Language and Environment for Statistical Computing; R Foundation for Statistical Computing: Vienna, Austria, 2013. Available online: http://www.R-project.org/ (accessed on 13 June 2014). 
56. RStudio. RStudio: Integrated Development Environment for $R$ (version 0.98.1091); Computer Software: Boston, MA, USA, 2014. Available online: http://www.rstudio.org/ (accessed on 31 March 2015).

57. Härdtle, W.; von Oheimb, G.; Meyer, H.; Westphal, C. Patterns of species composition and species richness in moist (ash-alder) forests of northern Germany (Schleswig-Holstein). Feddes Repert. 2003, 114, 574-586.

58. Swift, M.J.; Heal, O.W.; Anderson, J.M. Decomposition in Terrestrial Ecosystems; Blackwell Scientific Publications: Oxford, UK, 1979; pp. 1-372.

59. Orczewska, A. The impact of former agriculture on habitat conditions and distribution patterns of ancient woodland plant species in recent black alder (Alnus glutinosa (L.) Gaertn.) woods in south-western Poland. For. Ecol. Manag. 2009, 258, 794-803.

60. Turner, B.L. Resource partitioning for soil phosphorus: A hypothesis. J. Ecol. 2008, 96, 698-702.

61. Merunková, K.; Chytrý, M. Environmental control of species richness and composition in upland grasslands of the southern Czech Republic. Plant Ecol. 2012, 213, 591-602.

62. Honnay, O.; Hermy, M.; Coppin, P. Impact of habitat quality on forest plant species colonization. For. Ecol. Manag. 1999, 115, 157-170.

63. Pigott, C.D. Analysis of the response of Urtica dioica to phosphate. New Phytol. 1971, 70, 953-966.

(C) 2015 by the authors; licensee MDPI, Basel, Switzerland. This article is an open access article distributed under the terms and conditions of the Creative Commons Attribution license (http://creativecommons.org/licenses/by/4.0/). 